\title{
Ribištvo v najsevernejšem zalivu Mediterana: primer Slovenije
}

\author{
Alenka Janko Spreizer \\ UP FHŠ, Oddelek za antropologijo in kulturne študije in Inštitut za medkulturne študije \\ alenka.janko.spreizer@fhs.upr.si \\ Nataša Rogelja Caf \\ ZRC SAZU, Inštitut za slovensko izseljenstvo in migracije \\ natasa.rogelja@zrc-sazu.si
}

\section{Uvod}

Poglavje predstavlja ribištvo, ribogojstvo in dopolnile gospodarske dejavnosti, s katerimi se ukvarjajo ribiči na območju današnje Republike Slovenije od Miljskega do Savudrijskega polotoka. Prispevek se umešča v polje antropologije pomorstva in sloni na obsežnejši terenski antropološki raziskavi avtoric v obdobju med letoma 2002 do 2016 . Poleg pregleda teoretične literature, dela $\mathrm{z}$ arhivskimi ter s spletnimi viri sva namreč večino podatkov zbrali s pomočjo etnografskega beleženja. Ob etnografskem terenskem delu in opazovanju $\mathrm{z}$ udeležbo s pripadajočimi tehnikami sva prakticirali tudi hojo kot del mobilne etnografije, pri kateri sva se več let gibali - pluli in hodili - na območju današnjega slovenskega obmorskega prostora. Besedilo je nastalo $\mathrm{z}$ namenom predstavitve dinamičnega razvoja na področju slovenskega ribištva $\mathrm{v}$ Republiki Sloveniji $\mathrm{z}$ več preoblikovanji te gospodarske panoge v obdobju po drugi svetovni vojni do sodobnosti, kar odraža tudi struktura besedila. Zgradba besedila sledi procesu razvoja ribištva in marikulture, od opisa treh ribiških pristanišč v Kopru, Izoli in Piranu preko nastanka tovarn za predelovalno ribjo industrijo v omenjenem prostoru do dejavnega razvoja ribolova in ribjih tovarn $\mathrm{v} 2 \mathrm{O}$. stoletju ter nedavnih transformacij gospodarskega ribištva in uvajanja ribogojstva ter intenziviranja marikulture. Ribištvo in marikultura sta se zaradi razpada Jugoslavije, nastanka novih držav, ekonomskih sprememb in ob zmanjšanju ribolovnih krajev ter trgov preoblikovala tudi zaradi poli- 
tičnih in ekonomskih razlogov, kot sta npr. sprejem skupnih ribiških politik v Evropski uniji in vpeljava načela trajnostnega razvoja. Prišlo je do sprememb gospodarskih panog ribolova in predelovanja rib $\mathrm{v}$ smeri povezovanja ribištva $\mathrm{z}$ dopolnilnimi dejavnostmi, najpogosteje $\mathrm{s}$ kulinariko in turizmom.

Čeprav je predstavljena etnografija zasidrana v ribiških pristaniščih Kopra, Izole in Pirana, podatki pričajo o prepletenosti lokalnih, nacionalnih, regionalnih in širše globalnih trendih in procesih. Koprsko ribiško pristanišče se tako nahaja nedaleč stran od mednarodne Luke Koper, ki že vrsto let gosti turizem križark, obenem pa luka postaja pomembno regionalno tovorno pristanišče, ki daleč presega zgolj lokalne potrebe. Ribiške ladje so zasidrane ob pomolu, ki je bil nedavno obnovljen in dvignjen, zato, da bi ga ne zalivalo plimovanje morja, kar otežuje vkrcanje na barke, nama pojasni Nino. Žensk, ki bi se ukvarjale $\mathrm{z}$ ribištvom, je zelo malo in v pristanišču se jih redko sreča, razen kadar ne spremljajo moških na ribolovu. Ribištvo tako še vedno velja za moški poklic, a tudi tu je mogoče najti izjeme. Poleg občasne pomoči pri lovu, ekspertne vloge v ribiški pisarni, sodelovanju pri delu v turizmu, izobraževanju in muzejih so po podatkih do leta 2016 ženske delale tudi na tržnicah. V Kopru ni mogoče kupiti rib neposredno od ribičev z barke, kot lahko to storijo obiskovalci ribiškega pristanišča v sosednjem ribiškem mestu Izoli, ki je znano po nekdaj prisotni predelovalni industriji. Čeprav se je iz izolskih dimnikov nehalo kaditi ob koncu 8o. let 2o. stoletja, dokončno pa ob prehodu v kapitalistični gospodarski sistem po letu 1991, je obratovanje tovarne po drugi svetovni vojni v spominu prebivalcev Izole še vedno živo. $\mathrm{V}$ obnovljenih ribiških pristaniščih v Kopru in Izoli lahko še vedno najdemo estetske kamnite mize in zaboje za shranjevanje ribiške opreme.

V pristanišču v Izoli srečava nekaj moških, ki se danes zgolj občasno ukvarjajo $\mathrm{z}$ ribištvom. Zaradi pičlega ulova so številni prisiljeni kombinirati ribolovno dejavnost $\mathrm{z}$ drugimi dejavnostmi, kot so prevoz turistov, ribiški pikniki in drugi izleti. Rib je namreč v slovenskem morju vse manj pa tudi nerešeno vprašanje morske meje med Slovenijo in Hrvaško je dodalo svoj davek. Nekateri ribiči so se zaradi tega usmerili tudi v školjkarstvo - gojenje pedočev in ladink, tisti najprodornejši pa $\mathrm{v}$ gojenje ostrig. Redki so dobre volje in se neradi spustijo $\mathrm{v}$ pogovor $\mathrm{z}$ naključnimi radovedneži. Etnografska vprašanja o ulovu in meji ostajajo $\mathrm{v}$ takšnem vzdušju večkrat neodgovorjena in zavrnjena $\mathrm{z}$ vprašanjem, če morda provocirava s politiko. 


\section{Tržaški zaliv kot prizorišče slovenskega ribištva}

Tržaški zaliv, na obalah katerega se nahajajo tudi Izola, Piran, Portorož in Koper, "prizorišča« današnjega slovenskega ribištva, je najsevernejši del Sredozemskega morja in obsega približno $570 \mathrm{~km}^{2}$. Značilnost zaliva je zelo plitvo morje, povprečna globina morja je slabih $16 \mathrm{~m}$, le malo kje je zaliv globlji od $25 \mathrm{~m}$, največja globina $\mathrm{v}$ današnjem slovenskem delu pa je $37,5 \mathrm{~m}$, in sicer pred rtom Madona pri Piranu. Flišna pokrajina vzhodnega dela zaliva, ki sega od Trsta do skrajnega rta na Savudrijskem polotoku, je pogosto imenovana kot »istrska ali slovenska stran« zaliva. Po navedbah bioloških raziskav so dejavniki, ki vplivajo na morske organizme, predvsem slanost, temperatura in vsebnost kisika $\mathrm{v}$ morju. Ti dejavniki se le malo spreminjajo glede na geografsko razsežnost, bolj pa se spreminjajo glede na globino, letni čas, bližino ustja rek, stopnjo evtrofikacije ${ }^{\mathrm{I}}$ ipd. (Zei 1996, 356). Gospodarsko najpomembnejša skupina rib v Sredozemlju so klupeidi (drobne pelagične ribe, kot so sardele, papaline, inčuni, skuše), ki zavzemajo dve tretjini ribje produkcije $v$ Sredozemskem morju in so še nedavno, pred razrezom Ribe I in Ribe II leta 2012 - zadnjih dveh plovil podjetja Riba, predstavljale 93 \% celotnega morskega ulova države Slovenije (Zei 1977, 182; Marčeta 2001, 24). Klupeidi so v okviru Tržaškega zaliva pomembni predvsem za industrijski ribolov.

Politično si Tržaški zaliv danes delijo Hrvaška, Italija in Slovenija. Pomorska meja med Italijo in Jugoslavijo je bila določena z Osimskimi sporazumi, ki so veljavni od leta 1977 . Tako sta približno dve tretjini površine Tržaškega zaliva pripadli Italiji, dobra tretjina pa Jugoslaviji. Meja med republikama Hrvaško in Slovenijo se je v okviru Jugoslavije dokončno izoblikovala leta $1956 \mathrm{z}$ zakonom o dopolnitvi zakona o območjih okrajev in občin v Ljudski republiki Sloveniji (Marin 1992, 170). Po osamosvojitvi Republike Slovenije je ostala nedoločena še morska meja med Hrvaško in Slovenijo, ki je kljub arbitražni razsodbi še vedno predmet spora. Sporno je, ali naj mejna črta poteka po katastrski meji ali pa od izliva regulirane struge Dragonje v morje proti sredini zaliva. Spori v zvezi z to morsko mejo se dotikajo političnega diskurza in se kot problematika pojavljajo $\mathrm{v}$ medijih ob volilnih kampanjah ali drugih politično pomembnih dogodkih, na drugi strani pa se meja dotika tudi vsakdanjika ribičev v SV delu Jadranskega morja v okviru države Slovenije oziroma države Hrvaške.

1 Proces v ekosistemu, pri katerem narašča količina biomase - živalskih, rastlinskih organizmov, življenjskih združb ter odmrlega organskega materiala -, v vodi zaradi koncentracije anorganskih hranil, kot so nitrati in fosfati. 
Ribištvo med Miljskim in Savudrijskim polotokom je, glede na zgoraj povedano, gospodarska dejavnost, ujeta v mnoge zgodbe. Regionalni spori, nastanek novih nacionalnih držav po razpadu Jugoslavije, nova državna morska meja med Hrvaško in Slovenijo, tranzicijski in transformacijski procesi v Evropi, globalizacijski procesi in porast kapitalističnih lastniških ter tržnih razmerij v obalnih regijah so vsak po svoje vplivali na specifičen diskurz, ki določa izbrano geografsko področje in tu porajajoče se ekonomije. V nadaljevanju bodo predstavljeni drobci iz dvajsetega in enaindvajsetega stoletja, vezani na ribolov, ribjo predelovalno industrijo in ribogojstvo ob slovenski Obali, tri dejavnosti, ki jih lahko pod skupnim imenovalcem imenujemo gospodarsko ribištvo.

\section{Izola: nekdanje središče ribje predelovalne industrije}

Ko se danes sprehodimo po Izoli, ki velja za osrednje ribiško mesto na Obali, lahko opazimo ostanke stavb nekoč pomembne ekonomske panoge, ki stojijo prazne za žičnatimi ograjami zapuščenih dvorišč. Včasih se ljudje ob ograji nekdanje Ampeleje - Delamarisa ustavijo in pomislijo na delavke, ki so v poletni vročini zlagale ribe v majhne pravokotne embalaže, morda postojijo tam $\mathrm{z}$ mislijo o toplicah, ki so na tem mestu delovale še pred nastankom prvih tovarn ribjih konzerv, ali celo sanjarijo o prihodnjih investicijah, o dobičkih in hotelih, ki bi lahko zrasli na tleh zapuščenih industrijskih kompleksov. Ostanki nekaterih zapuščenih objektov še vedno stojijo tam, sredi poletnega turističnega vrveža Izole, in čakajo. Prežeti so s spomini, ujeti med včeraj in jutri, delujejo kot neme priče preteklih zgodb območja, ki segajo daleč čez meje današnjih nacionalnih držav. Ruševine stavb sprožajo tudi zgražanje nad opustošenimi prostori, ki v zavesti obiskovalcev še ne zasedajo pomembnega mesta na lestvici arhitekturne dediščine tega območja.

\subsection{Začetki ribje predelovalne industrije}

Začetki ribje predelovalne industrije segajo $\mathrm{v}$ obdobje konca 19. stoletja, ko so se v Izoli pa tudi v Kopru² pojavile prve tovarne za predelavo rib. Letnica 1879, ki krasi logotip podjetja Delamaris, obeležuje leto, ko je

2 Tovarne v Izoli so bile Société générale française CA - kasneje Ampelea; Tovarna Werchanek - Arrigoni - kasneje preimenovana v Argo in Droga; Degrassi - pozneje Riba; Delise; Torrigiani, Noerdlinger. V Kopru je znana večja tovarna De Langlade. Več o tovarnah ter njihovi kratki zgodovini si bralci lahko preberejo v besedilu T. Prešeren idr. (2018). 
Francoz Emile Louis Roullet kupil del zemljišča in obale v Izoli, kjer je začela delovati družba Société générale française CA in zgradila prvo tovarno za predelavo rib, vrtnin, zelenjave in sadja (Terčon 1990, 123). V tovarni so proizvajali konzerve sardin, jegulj, graha in mesa, ribe pa so kupovali od lokalnih ribičev in jih uvažali tudi iz tujine (npr. jegulje iz Beneške lagune in slanike z Norveške). Konzervirane slive, uvožene iz Bosne, so se dobro prodajale predvsem v Angliji. V tovarni so izdelovali tudi gnojilo iz ribjih ostankov, ki so ga prodajali na Dunaj (Kramar 1988). Francosko tovarno, kot so jo ljudje imenovali, je kasneje odkupila Anglo-avstrijska banka iz Trsta, tovarna pa je uspešno delovala do prve svetovne vojne. Po vojni se je preimenovala v Ampeleo.

Drugo večjo tovarno v Izoli, znano kot Arrigoni (kasneje pa kot Argo in Droga), je leta 1881 ustanovil dunajski podjetnik Carlo Werhanek, čigar družba je tovarno predelovalne ribje industrije ustanovila že leta $1867 \mathrm{~V}$ Devinu pri Trstu. Poleg teh dveh večjih tovarn, ki sta $z$ ruševinami še vedno prisotni v prostoru, opazimo še tretjo tovarno Degrassi (kjer se danes nahajajo prostori podjetja Riba). Kasneje so se razvile še druge tovarne, kot so Troian, Noerdlinger, Delise, D'Agostini in Società Italiana. Med prvo svetovno vojno se je proizvodnja $\mathrm{v}$ večini tovarn za konzerviranje rib ustavila, po vojni pa so zopet pričele $z$ delovanjem. Leta 1938 je začela delovati tovarna Ampelea, ki je konzervirala ribe, kot so skuše, sardoni in tune. Poleg ribjih konzerv je proizvajala tudi ribje olje, ribjo moko, ribje filete uvoženih rib, marmelado, konzervirali pa so tudi zelenjavo, slane inčune, paradižnik in paradižnikovo mezgo. V Izoli je Ampelea zgradila tudi ladjedelnico in ustanovila lastno ribiško ladjevje, ki je že leta 1939 imelo 32 ladij, na katerih so bili zaposleni predvsem ribiči iz Izole (Terčon 1990, 124-25).

Tudi tovarna Arrigoni je leta 1941 ustanovila svojo ribiško floto, ki je prav tako zaposlovala Izolane in prebivalce iz okolice. Ladje Arrigonija so kasneje prešle v last podjetja Riba, d. d. Riba, d. d., je od leta 1948 do leta 1951, ko je njeno ladjevje prevzela Istria Pesca, oskrbovala tovarno Arrigoni z ribami. Tovarna Riba, d. d., je nato z ribjo preskrbo nadaljevala še do leta 1954, ko je zaradi konkurence državnih podjetij Riba Izola in Ribič Piran Riba, d. d. dokončno prešla v likvidacijo. Vsi ribiči izolske Ribe, d. d., naj bi bili italijansko govoreči Izolani, ki so po letu 1954 zaradi nove politične situacije (aneksacija) začeli množično odhajati, zaradi česar so omenjene družbe ostale brez glavnine delavcev. Na področje obalnih mest so se začeli priseljevati ljudje iz vse Slovenije in iz hrvaških istrskih obalnih mest, npr. iz Funtane, kot tudi iz drugih krajev, z znatnim številom iz Dalmacije (Terčon 1990). 


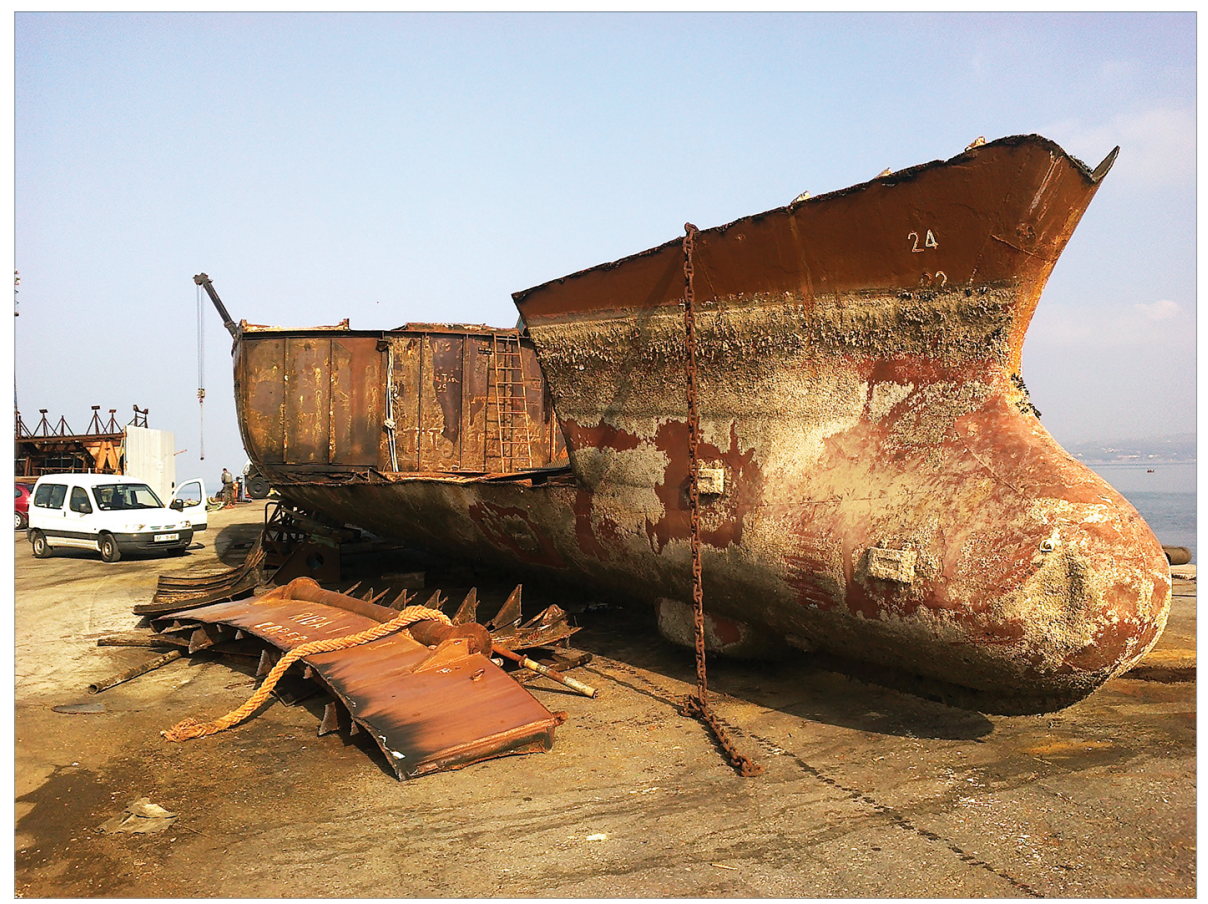

Slika i. Razrez ladjevja Ribe leta 20 ı (foto: Alenka Janko Spreizer)

\subsection{Ribja predelovalna industrija v Sloveniji po letu 1954}

Jugoslovanko državno podjetje Riba Izola, ki je začelo delovati leta 1954, in podjetje Ribič iz Pirana, ustanovljena leta 1953, sta nadaljevala $\mathrm{z}$ dejavnostjo. V prihodnjih letih sta obe podjetji učinkovito delali in zaposlovali dijake nove šole za ribištvo s sedežem v Piranu. Leta 1951 je namreč v Piranu začela delovati ribiška šola, ki se je postopoma razvila iz enoletne $v$ triletno šolo. Kot navaja Kodrič (1962), je bilo v prvem letu vpisanih 19 dijakov (2 iz Pirana, 1 iz Izole, 4 iz Kopra, 11 iz Sežane, 1 iz Trsta), v naslednjih letih pa so dijaki prihajali iz Celja, Buzeta, Ljubljane, Brežic ter iz Dalmacije in Bosne. Ribiči, zaposleni v slovenskih podjetjih, so ribarili tudi v Dalmaciji, kjer so imeli ob jadranski obali skladišča (Mali Lošinj, Kali, Supetarska Draga). Podjetje Ribič je bilo leta 1959 razpuščeno, njegovo premoženja pa preneseno na podjetje Riba Izola. $\mathrm{V}$ istem letu je bila ustanovljena tudi tovarna za konzerviranje Delamaris Izola, čigar ime je sestavljeno iz imena koprske tovarne De Langlade ter tovarn Ampeleje in Arigoni, pripona »is« pa naj bi bila krajšava za ime mesta Isola/Izola. Spremembe upravljanja, ki so se zgodile v naslednjih letih, so bile posledica vzpostavitve združenega poslovne- 
ga sistema ribiške in predelovalne industrije, na čelu s Holding Delamaris, p. o., Izola (Delmar, d. o. o., Frigomar, d. o. o., Delsa, d. o. o., Lera, d. o. o., in Riba, d. o. o.; Lisjak 1999).

Kljub temu, da se je z ribolovom ukvarjala Riba, d. o. o, je v lokalnem jeziku ime Delamaris še vedno v uporabi tako za ribiško floto podjetja Riba, d. o. o., in tovarno ribjih konzerv, ki pa od leta 2014 deluje v Pivki. Od ladjevja je ostala le še ladja Jež; barki Riba 1 in 2, primerni za industrijski ribolov z vlečnimi mrežami, sta bili razrezani jeseni leta 2012 .

\section{Piran in »najbolj trajnostni« priobalni ribolov}

V Piranu se ribiči radi pohvalijo, da so najbolj trajnostni, saj naj bi med njihovim ladjevjem ne bilo več bark z vlečnimi mrežami, ki orjejo po dnu morja. Ribiško pristanišče je, kot nama povedo domačini, prijaznejše ribičem, saj je opremljeno s pontonskimi pomoli, ki ob plimi potujejo ob barkah, kar olajšuje dostop na čolne. Vstop v pristanišče krasita dva svetilnika, zgrajena v začetku 2o. stoletja. Na pomolu najdemo zaboje z opremo, poslikane $z$ motivi starih razglednic. Nedaleč od mesta, v Piranskem zalivu, se nahaja ribiški rezervat, ki je med drugim znan po tradicionalnem ribolovu na ciplje. Piranski zaliv je za nekatere ribiče tudi kraj, ki se mu je zaradi nejasno rešene meje s Hrvaško bolje izogniti. Meja je bila namreč določena $\mathrm{z}$ arbitražo, a nepriznana s strani hrvaške države. Kot taka, nepriznana in nejasna, je meja prostor potencialnih kazni in sporov, kompleksen prostor mnogoterih interesov, ki ga bova v tem članku pustili ob strani. Raje kot sporni meji, ki zahteva svoj članek, se bova v nadaljevanju posvetili zgodovinopisnim razlagam podeljevanja ribolovnih pravic v Piranskem zalivu.

Če segajo začetki ribje predelovalne industrije v obdobje konca 19. stoletja, je aktivnost priobalnega ribolova veliko starejša. Poleg tehnik ribolova in tehnologije plovil zaznamuje to dejavnost tudi zgodovina upravljanja morja in priobalnih področij. Eni prvih pisnih zgodovinskih virov, ki govorijo o tradiciji ribolovnih pravic v Piranskem zalivu, segajo v 6. stoletje. Srednjeveške mestne komune so postopoma pridobile pravico do razpolaganja nad glavnino priobalnih voda, kar je v zahodni in južni Istri veljalo tudi po vzpostavitvi nadvlade Beneške republike, saj ta ni posegala v neposredno lastništvo in izrabo voda mestnih komun (Mihelič 1998, 7). Piranska komuna je razpolagala $\mathrm{z}$ večjim delom ribiških lovišč ob Piranu (zapisi omenjajo komunalna lovišča v Strunjanu, Fažani, Paderni, v Palus maior, Sečovljah, Savudriji, ribiška lovišča Piscaria parva in Piscaria Cala, val de Remoleo in ribiško območje Siparja), ki jih je oddajala v zakup. Pravice 


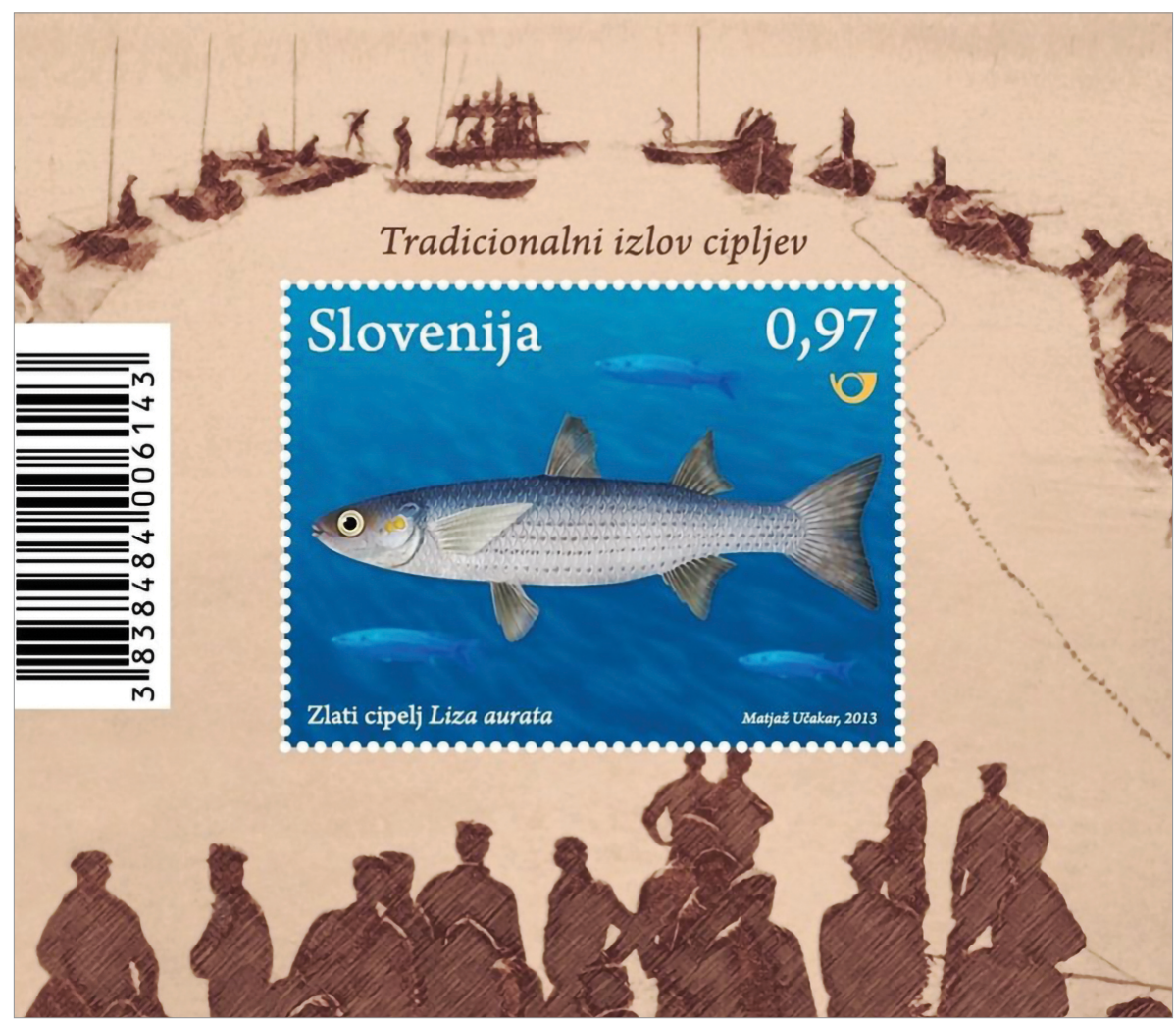

Slika 2. Stiliziran prikaz lova na ciplje v Piranskem zalivu ob začetku prejšnjega stoletja, na znamki RS, natisnjeni leta 2013

do ribolova je komuna $\mathrm{v}$ zakup uporabnikom dajala na vsakoletni dražbi. V 14. stoletju je bilo zakupno obdobje časovno omejeno; od 1. aprila do Mihaelovega, 29. septembra, so bila piranska lovišča odprta vsem, v preostalem delu leta pa samo zakupnikom.

Francoska kratkotrajna zasedba je prinesla nekaj novosti v okviru ribolovnih pravic: vpeljana je bila svoboda ribolova, odpravljene so bile ribolovne pravice mestnih komun in zemljiških gospodov, ukinjen je bil tudi ribji davek na prodajo rib. V obdobju Habsburške monarhije se je vzpostavilo staro stanje mestnih in zemljiškogosposkih pravic, pri tem pa je v tridesetih letih 19. stoletja primorski gubernij natančneje opredelil ribolovne pravice - morje je razglasil za »svobodno«, obalni pas, ki je bil namenjen ribolovu lokalnega prebivalstva, pa je bil širok eno miljo. Po drugi svetovni vojni je bil Piranski zaliv vključen v Cono B Svobodnega tržaškega ozem- 
lja, leta 1954 pa sta bila ta cona in z njo Piranski zaliv dodeljena Jugoslaviji in s tem stopila pod jugoslovanske in slovenske zakone o morskem ribištvu (Mihelič 1998, 7-14).

Podatki za leto 1911 kažejo, da je bilo v Izoli 900 ribičev in 14.000 stoječih mrež, medtem ko je imel Rovinj npr. v istem letu 600 prijavljenih ribičev, ob Jadranskem morju najmočnejši ribiški center Komiža na Visu pa 1.500 ribičev (Zei 1957, 82). Če primerjamo še obravnavane kraje ob vzhodni obali Tržaškega zaliva, lahko ugotovimo, da je bil pomen Kopra in Pirana za gospodarski ribolov znatno manjši kot pomen Izole ter da je imel Koper leta 1911400 stoječih mrež, Piran pa še manj. Po seznamu iz leta 1927 naj bi število ribičev kasneje upadlo zaradi vojne, saj je bilo tega leta v Izoli registriranih 750 ribičev, ki so imeli 180 ribiških čolnov (Bezek 1979). Na začetku prve svetovne vojne je bil lov v teritorialnih vodah ob nekaterih delih Tržaškega zaliva celo prepovedan (Tome Marinac 1994, 112). Obe svetovni vojni v 2o. stoletju, negotova politična situacija in kasneje eksodus italijansko govorečega prebivalstva iz obalnih mest današnje Slovenije so povzročili spremembe v gospodarskem ribolovu na tem območju. Statistike ulova za obravnavano območje ne povedo veliko, saj se je ulov po drugi svetovni vojni povečal $v$ splošnem obsegu zaradi uvajanja novih ribolovnih tehnologij. Po podatkih za Sredozemlje naj bi ulov leta 1947 leta znašal 18 tisoč ton rib, v letu 1977 pa 70 tisoč ton rib (Zei 1977, 180). Največ povedo statistike migracij prebivalstva po drugi svetovni vojni ter slika ekonomskih dejavnosti prebivalstva obravnavanega območja. Podatek o prebivalcih za občino Izolo kaže, da je bilo leta 1944 v občini 10.909 prebivalcev, leta 1959 pa le 5.799 (Tome Marinac 1994). Najštevilnejše migracije so bile prav v obalnih mestih, ki so imela največji odstotek italijansko govorečega prebivalstva (Pletikosić 1995, 21). Izseljevali so se predvsem trgovci, obrtniki in ribiči. Statistika iz leta 1957 za občino Izola navaja, da je bilo v družbenem sektorju prijavljenih 198 ribičev, v zasebnem pa le 9. Samo eno leto prej je bilo v zasebnem sektorju 131 stalnih in 70 sezonskih ribičev (Terčon 1990).

\subsection{Ribolov danes}

In danes? Leta 2014 je bilo 169 registriranih ribiških gospodarskih plovil, od tega je bilo 92 aktivnih (to pomeni, da so šla vsaj enkrat na ribolov in da so oddala en ribiški dnevnik letno). 155 registriranih plovil je bilo krajših od 12 metrov in opremljena so bila s pasivnimi ribolovnimi orodji. Samo 78 ladij je bilo aktivnih. Sklenemo lahko, da večino slovenske ribiške flote danes sestavljajo ladje, velike od 6 do 12 metrov. Med letoma 2008 in 2013 


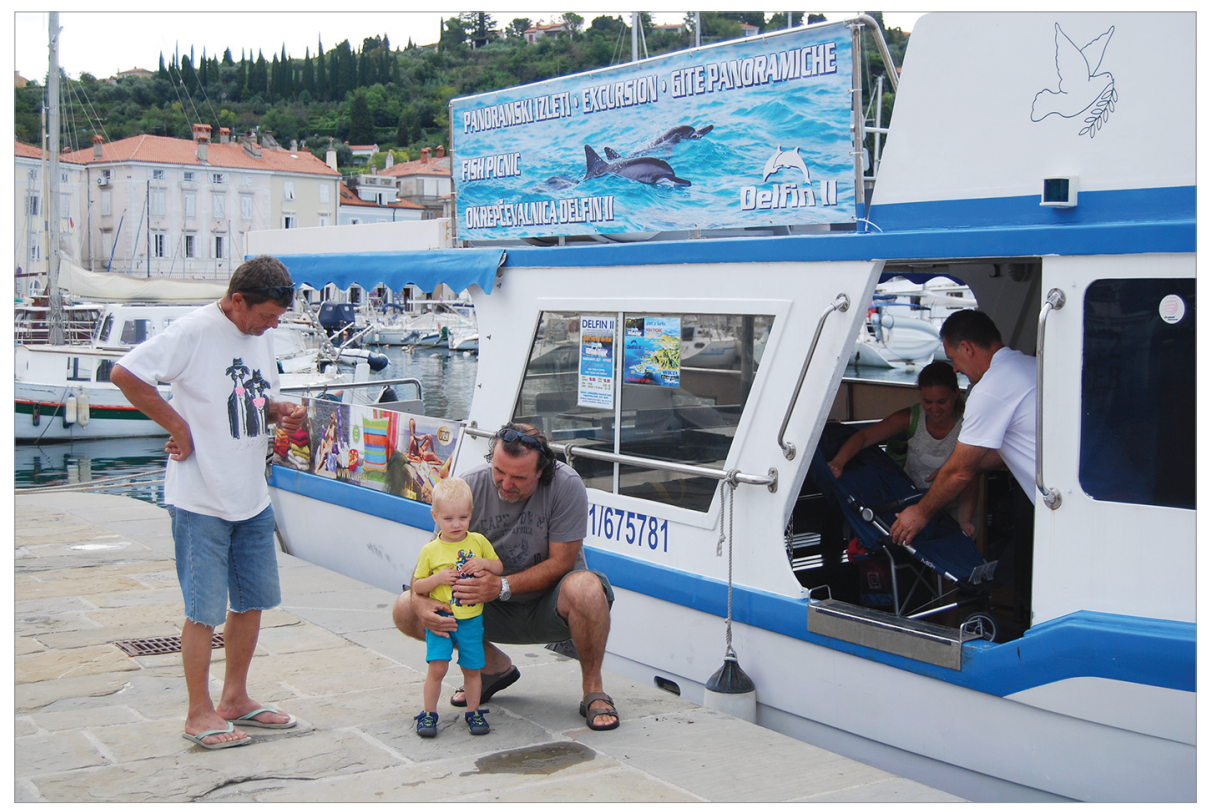

Slika 3. Z ribiči na izlet (foto: Nataša Rogelja Caf)

se je flota zmanjšala za $5,5 \% \mathrm{v}$ številu ladij in za $40 \%$ glede bruto tonaže in moči motorjev, zaradi razreza dveh največjih ladij za industrijski ribolov. Kapaciteta vseh segmentov registriranih plovil slovenskega ribiškega ladjevja je bila leta 2014597 bruto ton (GT). Leta 2014 je bilo v ribištvu zaposlenih 125 oseb, in sicer v enoti FTE, medtem ko je delovalo 142 ribiških podjetij (Janko Spreizer in Rogelja Caf 2020). Lahko rečemo, da je na obravnavanem območju danes ribištvo večinoma dopolnilna dejavnost kot tudi dejavnost, namenjena prostemu času. Zaradi novonastale politične situacije, izlova in drugih dejavnikov so se danes mnogi ribiči odločili, da ribiško dejavnost dopolnjujejo z drugimi panogami, npr. s kmetijstvom in turizmom (Rogelja in Janko Spreizer 2017).

\section{Morsko ribogojstvo}

Morsko ribogojstvo je ena izmed dejavnosti marikulture, to je gojenja rib, školjk in drugih morskih organizmov, npr. rakov in alg. O prisotnosti ribogojstva v priobalnem pasu pričajo arheološke raziskave na območju portoroške plaže in pri Fizinah pri Portorožu, kjer so ob pristaniškem objektu iz rimskega obdobja odkrili dva zaprta bazena za gojenje ali shranjevanje rib (piscina vivaria; Gaspari idr. 2016). 
Ideje o razvoju ribogojstva so bile od nekdaj umeščene večinoma na območju strunjanske lagune. V 20. stoletju ribogojstvo v današnjem slovenskem priobalnem prostoru ni bilo močno razširjeno, je pa $\mathrm{v}$ sedemdesetih letih 2o. stoletja prisotno prizadevanje biologov, da bi se v območju plitvega lagunarnega sistema na severovzhodni obali Jadranskega morja, v tedanji Socialistični Republiki Sloveniji, poleg obstoječega gojenja školjk v nekdanji skupni državi (v Limskem kanalu v Istri in v okolici Stona na Pelješcu) postopoma razvilo tudi intenzivno ribogojstvo. $S$ tem namenom so se biologi raziskovalno posvetili tej nalogi in poskušali vzpostaviti bolj intenziviran sistem. Ideje za razvoj »ribogojništva« so bile naslovljene na preteklost in so govorile o domnevni tradicionalni prisotnosti omenjene dejavnosti v tem delu plitvega morja.

Po izročilu naj bi namreč morsko laguno Stjužo (chiusa, ital. zaprta) pred 400 leti umetno zaprli z nasipom, na katerem se danes nahaja del plaže, in uredili ribogojnico, kjer so do sredine 2o. stoletja gojili ciplje, brancine, orade in jegulje. O prisotnosti ribogojstva na tem območju pripoveduje tudi poročilo tržaške pristaniške uprave, ki omenja strunjansko Stjužo (chiusa di Strugnano). Poročilo iz leta 1903, ki je bilo namenjeno avsto-ogrski državni upravi za pomorstvo, to dejavnost opisuje takole: »V dolini Strunjan pri Piranu deluje ribogojni zadrževalnik, ki se ga spomladi polni z mladicami, ki se jih goji tam do prvih dni novembra. Gojenje poteka na enak način kot $v$ gradeških ribogojnicah. Vrednostni obseg posla ne presega 200 kron." (Delise 2010, 24).

Sledeč opisani tradiciji so podobno takratni jugoslovanski biologi poročali, da načrtujejo ulov, pozneje pa tudi gojenje ribjih mladic, cipljev in brancinov. Pozneje je bilo načrtovano ribogojstvo cipljev in brancinov v večjih, zamreženih kletkah, tudi v bolj globoki vodi Strunjanskega zaliva. Poročila pričajo o stalnih težavah zaradi vzreje mladic, razpolaganja s pičlimi finančnimi sredstvi in odsotnosti financiranja pomembnega čuvaja, vandalizma neznanih storilcev in slabega vremena. Po nekajletnih poizkusih skorajda prostovoljnega dela in neuspešni zagotovitvi pogojev za financiranje so se načrti o razvoju ribogojstva $\mathrm{v}$ širšem koprskem območju izkazali za neuspešne. Več let zapored so si sodelavci Inštituta za biologijo in Morske biološke postaje v sodelovanju s takratnim podjetjem Droga prizadevali pridobiti finančna sredstva za delo stažista in ribiškega čuvaja. Izdelali so tudi več zamreženih kletk in uredili območje obale $\mathrm{z}$ dostopom do eksperimentalnih kletk, z lokalnimi skupnostmi so dosegli soglasje, da bi bilo to območje namenjeno »ribogojništvu«. (Zei 1978-1980) Poročila o 
nalogi Morsko ribogojništvo v strunjanski laguni govorijo o velikih težavah, saj podjetje Droga ni imelo posluha za razvoj ribogojstva in ni izpolnilo svojih pogodbenih obveznosti. Po večkratnih poskusih vzgojiti zdrav ribji zarod od mladic naprej in ob različnih težavah v osemdesetih letih prejšnjega stoletja je bilo slednjič ribogojstvo opuščeno, v Strunjanskem zalivu pa so v kasnejših letih začeli gojiti školjke.

Ribogojstvo se je razvijalo tudi v portoroškem ribjem rezervatu. V preteklosti je delovala ribogojnica v lasti podjetja Mariva, d. o. o., ki je bila leta 2003 prodana Ugu Fondi, in ribogojnica Ribič, ki je po letu 2005 propadla (Forte 2016). V omenjeni ribogojnici so sprva gojili brancina in orado, $\mathrm{v}$ kasnejših letih pa so gojenje orad opustili. Čeprav je zgodba ribogojstva ob današnji obali precej luknjičasta, povezana $z$ več lastniki ter nesistematičnim razvijanjem do leta 2006 in včasih težavna, pa se $z d i$, da bo morda $v$ prihajajočih desetletjih pomembno vlogo odigralo prav ribogojstvo. Danes v slovenskem obmorskem prostoru deluje več školjkarjev v Seči, Strunjanu in na Debelem rtiču in le ena morska ribogojnica, ki jo je postavila družine Fonda. Ribogojnica je bila leta 2014 prodana italijanskemu podjetju Vale Ca' Zuliani iz okolice Ravene, ki je podjetje kupilo zaradi razvite blagovne znamke piranskega brancina in nadaljuje $z$ vzrejo piranskega brancina ter razvijanjem ribogojniškega turizma. Nekateri domačini celo menijo, da je tradicionalni piranski cipelj dobil svojega tekmeca, piranskega brancina, hranjenega s prvovrstno hrano in pakiranega $\mathrm{v}$ belih embalažah $\mathrm{z}$ ličnimi nalepkami, ki pričajo o kontroli kakovosti.

\section{Zaključek: slovensko gospodarsko ribištvo v morju projektov}

Danes, ko ladjevja Ribe praktično ni več, podjetje Delamaris pa od leta 2014 deluje v Pivki, lahko slovensko gospodarsko ribištvo spremljamo v okviru delovanja Evropskega ribiškega sklada, projektnega financiranja in idej trajnostnega razvoja. Od leta 2008 do leta 2016/17 je aktivno delovala t. i. Ribiška pisarna na področju projektnega vodenja, prijav na projekte kot tudi ustanavljanja teles, potrebnih za pridobivanje evropskega denarja, namenjenega gospodarskemu morskemu ribištvu. Kot druge države EU je morala namreč tudi Slovenija glede na zahteve četrte osi Evropskega ribiškega sklada ustanoviti in organizirati ribiško lokalno akcijsko skupino, ki so jo v slovenskem primeru imenovali obalna akcijska skupina (OAS) ${ }^{3}$. Ožja delovna skupina ribičev OAS je kasneje pripravila osnovo za Lokalno stra- 
tegijo trajnostnega razvoja ribištva na obalnem območju (LSTRR). Obalna akcijska skupina, poimenovana »Ribič«, je vključevala 46 partnerjev, med njimi 26 iz privatnega ribiškega sektorja, 15 zasebnih partnerjev izven ribiškega sektorja in 5 javnih institucij. Po ustanovitvi OAS in LSTRR, ko so bili zadovoljeni vsi osnovni pogoji za pridobivanje sredstev iz Evropskega ribiškega sklada, je OAS Ribič izdala javno povabilo za oddajo projektov, ki bi sledili implementaciji LSTRR. V naslednjih letih je bilo izbranih, financiranih in realiziranih 17 projektov, iz Ribiške pisarne pa so podali sledečo izjavo za javnost, objavljeno v Primorskih novicah:

Ponosni smo, saj nihče ni verjel, da bomo uspeli. Tudi zato, ker 4. os operativnega programa za razvoj ribištva deluje »od spodaj navzgor «, kar je v Sloveniji novost. [...] Verjamemo, da smo s temi projekti odprli vrata tudi drugim ribičem za naslednjo evropsko ribiško perspektivo 2014-202o in da bodo prihodnji projekti še bolj prispevali $k$ povezovanju ribištva $z$ lokalnim okoljem. (Vidrih 2013).

Čeprav zgornja izjava deluje optimistično, naj pričujoči prispevek zaključimo s sprehodom po slovenskem obmorskem prostoru ter $\mathrm{z}$ omembo sprejetih projektnih rezultatov v okviru OAS Ribič, ki na svojstven način osvetli situacijo morskega gospodarskega ribištva. Na sprehodu po priobalnem pasu ob morju lahko dandanes opazimo številne table, ki nas opozarjajo na projekte, pridobljene preko Evropskega ribiškega sklada. Večinoma so to turistično obarvani projekti, povezani z gastronomijo, vzgojo školjk, s turizmom, z ekologijo in izobraževanjem. Opazimo lahko dve plovili, EKO 1 in EKO 2, last dveh lokalnih ribičev - školjkarjev, ki sta ribiško dejavnost začela kombinirati $\mathrm{z}$ gojenjem školjk kot tudi s potapljaškimi in $\mathrm{z}$ izobraževalno-kulinaričnimi izleti, vezanimi na morsko gastronomijo in gojenje školjk. Projekti ribiškega sklada so vidni tudi v napisih nad ribogojnicami; kar štiri zasebna podjetja, ki so se prijavila na razpis Ribiškega sklada, so namreč dobila financiranje za ribogojstvo, izobraževanje o ribogojstvu ali za druge turistične aktivnosti, povezane $\mathrm{z}$ ribogojstvom in ekoturizmom. Denar je bil npr. investiran v nakup ekološkega plovila in opreme za turistične ture, na katerih si obiskovalci lahko ogledajo ribja gojišča. Prav tako je bila iz projektnega denarja ribiškega sklada financirana knjiga o podvodnem svetu Pirana, posnet pa je bil tudi dokumentarni film, ki je promoviral blagovno znamko Fonda. Tri projekte od sedemnajstih izbranih so realizirali ribiči, ki so se že prej ukvarjali s povezovanjem ribištva in turizma; kupljeno je bilo novo plovilo, namenjeno izključno turistični dejavnosti, 
ena ribiška barka je bila spremenjena $\mathrm{v}$ turistično plovilo, projektni denar pa je bil investiran tudi v mobilno kuhinjo z morsko hrano. Nakup dodatnega plovila je bil realiziran $\mathrm{v}$ partnerstvu $\mathrm{z}$ gimnazijo iz Pirana in s piranskim akvarijem. Trije raziskovalni projekti so se osredotočili na ekonomske in prehrambne vrednosti rib v slovenskem morju, na ribiški turizem in raziskovanje ribištva kot poklica mladih. Dva projekta je pridobil inštitut Mediteranum, ki je $\mathrm{z}$ denarjem ponatisnil knjigo in povečal zbirko školjk v razstaviščnem prostoru inštituta.

Predlagani cilji lokalne ribiške strategije in Evropskega ribiškega sklada so bili doseženi. Projekti so se naslavljali na aktivnosti, povezane $\mathrm{z}$ osnovnimi evropskimi regulativi, kot npr diverzifikacija, turizem, ohranjanje okolja ipd. Takšna merila so bila blagodejna predvsem za področje povezovanja ribištva in turizma ter akvakulturo, medtem ko so za mnoge druge delovala izključevalno (za tiste, ki se ne želijo ali ne morejo ukvarjati s turizmom npr.). In čeprav mnogi ribiči, ki sva jih v najini raziskavi intervjuvali, niso podpirali razvoja marikulture ob današnji slovenski obali (predvsem zaradi negativnega vpliva na okolje), so ribogojnice, školjčišča in turistične ladje $\mathrm{v}$ naslednjih letih izpodrinile ribolov na tem območju. Razvoj projektov po letu 2016 v okviru Evropskega ribiškega sklada nakazuje prihodnost, usmerjeno predvsem $\mathrm{v}$ marikulturo.

\section{Viri in literatura}

Objavljeni vir

PN: Primorske novice

Vidrih, P. 2013. »Ribičem uspel dober ulov denarja iz EU.« Primorske novice, 18. november, 2013.

\section{Literatura}

Bezek, V. 1979. Analitični inventar fonda občine Izola. Koper: Pokrajinski arhiv Koper.

Delise, F. 2010. L'Isola dei pescatori. Izola: Il Mandracchio.

Forte, J. 2016. »Indikatorji obremenitve okolja z marikulturo.« Magistrsko delo, Univerza v Ljubljani.

Gaspari, A., S. Karinja, M. Erič, S. Poglajen in P. Čerče. 2016. »Rimski pristaniški objekt z ribogojnico v Fizinah pri Portorožu.« Annales - Ser. Hist. Sociol. 16 (2): 421-42. 
Janko Spreizer, A., in N. Rogelja Caf. 2020. „Small Scale Fishery in the Northeastern Adriatic: From Borders to Projects.« V Status and resilience of small-Scale Fisheries in Europe: In the shade of the CFP reform and economic crisis, ur. J. Pascual-Fernandez, C. Pita in M. Bavinck. V tisku. Cham: Springer.

Kodrič, V. 1962. »Ribiška šola v Piranu.« V Slovenski pomorski zbornik, ur. F. Leben idr., 109-13. Koper: Klub pomorščakov.

Kramar, J. 1988. Izola mesto ribičev in delavcev. Koper: Lipa.

Lisjak, B. V. 1999. Delamaris 1879-1999: 120 let iz morja v konzervo. Izola: Delamaris.

Mihelič, D. 1987. »Ribolov na srednjeveškem piranskem področju.« Arhivi 10 (1-2): 9-11.

Mihelič, D. 1998. "Piranski zaliv: K tradiciji ribolova in ribolovnih pravic.» Annales 7 (14): 7-18.

Pletikosič, I. 1995. »Prostorski učinki migracij v Piranu.« Diplomska naloga, Univerza v Ljubljani.

Prešeren, T., A. Janko Spreizer, N. Kolega, P. Kavrečič in S. Gombač. 2018. »Pot tovarn kot pripoved o dediščini ribištva in predelovalne industrije s poudarkom na Izoli.« Studia universitatis hereditati 6 (2): 63-75.

Rogelja, N., in A. Janko Spreizer. 2017. Fish on the Move. Cham: Springer.

Terčon, N. 1990. »Razvoj industrijskega ribištva na slovenski obali v letih 19451959. Kronika: časopis za slovensko krajevno zgodovino 37 (1-2): 123-34.

Tome Marinac, B. 1994. Etnološka topografija slovenskega etničnega zemlja: 20. stoletje. Občina Izola. Ljubljana: ZIFF.

Zei, M. 1957. »Morsko ribištvo v Slovenskem Primorju. "Geografski obzornik 4 (4): 81-84.

Zei, M. 1977. »Stanje jadranskega ribolova s posebnim ozirom na naše ribiške probleme."Slovensko morje in zaledje 1 (1): 179-90.

Zei, M.. 1978-198o. Morsko ribogojništvo v strunjanski laguni: raziskovalno poročilo. Ljubljana: Inštitut za biologijo in Morska biološka postaja

Zei, M. 1996. »Ribe severnega Jadrana." V Narava Slovenije, stanje in perspektive, ur. J. Gregori, A. Martinčič, K. Tarman, O. Urbanc-Berčič, D. Tome in M. Zupančič, 356-61. Ljubljana: Društvo ekologov Slovenije. 


\section{Spletni vir}

Marčeta, B. 2001. "Status of Slovene Research and Fishery on Small Pelagics.» AdriaMed Technical Documents 3: 24-29. http://www.faoadriamed.org/ pdf/publications/td3/web-td-3-MA.pdf.

\section{Summary}

\section{Fishing in the Northernmost Bay of the Mediterranean: The Case of Slovenia}

The chapter presents fisheries, aquaculture, and complementary economic activities that fishermen perform in the present-day Republic of Slovenia. The article presents topics from maritime anthropology and covers a part of the authors' more extensive diachronic anthropological field research in the Slovene coastal area between 2002 and 2016. In addition to the classical anthropological cabinet method, such as reviewing theoretical literature and working with archival and online resources, the authors collected data through anthropological ethnographic recording and participatory observations in the coastal towns of Koper, Izola and Piran. Conversely, the authors also practised mobile ethnography-sailing and walking-between the peninsulas of Milje and Savudrija. The purpose of the text was to present the dynamic development of fisheries in the period after the Second World War to the present day in the Republic of Slovenia. The structure of the text follows the process of fisheries and mariculture development, from a cursory description of the three fishery ports of Koper, Izola and Piran, through the establishment of food and fish processing factories in the area, its development in the 2oth century, to the recent transformations of commercial fisheries and mariculture towards the combination of education and tourism. Fisheries and mariculture were transformed due to political reasons after the breakup of former socialist Yugoslavia in 1991 when Slovenia gained independence. The chapter analytically describes the socio-economic changes of fisheries and the decline of fishing areas and markets. The authors explain how the adoption of the Common EU fisheries policy has reduced the fisheries sector on the one hand and how, for ecological and sustainability reasons, it has also improved it with a combination of activities such mariculture, education, culinary and tourism. 